\title{
Role of CEO Age in Determining Executive-employee Pay Gap in Chinese Listed Manufacturing Companies: A Perspective of Risk Aversion
}

\author{
Changzheng Zhang ${ }^{1 *}$, Qian Guo ${ }^{1}$ and Lili $\mathrm{Hu}^{1}$ \\ ${ }^{1}$ Xi' an University of Technology, School of Economics \& Management, Xi'an China \\ *Corresponding author: zcz7901@163.com,383531334@qq.com,251158817@qq.com
}

\begin{abstract}
The paper investigates the effect of CEO age on executive-employee pay gap (EEPG), a newly focused dimension of executive compensation arrangements by the literature, by choosing the panel data consisting of 3495 firm-years in Chinese listed manufacturing companies during 2010-2014 as the research sample. Empirical analysis based on multiple regression analysis adopting the method of OLS by applying SPSS19.0 makes a new finding, i.e., there is a positive relationship between CEO age and EEPG, which holds robust with the change of the measures. Further investigation on the determination mechanism of CEO age on EEPG show that older CEOs intend to set relatively lower EEPG out of their risk aversion needs.
\end{abstract}

\section{Introduction}

A key question in leadership, corporate governance and strategy management research is whether chief executive officer (CEO) matters. A growing literature in the above fields points to the central role of CEOs' individual characteristics in explaining corporate outcome variables such as investment, mergers, or financial decisions, given their role as the top decision-makers in the firm and their data availability due to their positions [1]. The spectrum of CEO traits ranges from age, gender, tenure, risk-aversion, education, and childhood experiences to behavioral biases such as loss aversion, confirmation bias, or overconfidence[2,3]. Among the mentioned CEO traits, CEO age is receiving more and more attention from the scholars, since CEO age may be systematically related to risk preferences both due to the changing incentives over the CEO's career and due to the changing CEO characteristics, both physiological and psychological, as the CEO gets older[4,5].

Effects of CEO age on the choices of organizational policies have been investigated to good degree. Though Serfling (2014) [5] cites anecdotal evidence that portrays younger CEOs as more risk-seeking, Chevalier and Ellison (1999)[6] suggests younger CEOs display risk-averse behavior because they face greater risk of being fired following poor performance. Bertrand and Marianne (2003) argue that physiological changes may lead older CEOs to prefer 'the quiet life' [7], which could pull them away from corporate policies or events that require expending high levels of energy. DavidsonIII et al. (2007) [8] find that firms in which CEOs are nearing retirement age have large discretionary accruals in the year prior to turnover. Nulla(2014)[9] indicates that there is a relationship between CEO compensation and CEO age using accounting performance as a benchmark. Matthew A. Serfling (2014)[5] documents a negative relation between CEO age and stock return volatility, which is consistent with the prediction that risk-taking behaviour decreases as CEOs become older; Brandon(2015)[10] confirm that CEOs promoted during their 40s negatively influence firm value, while CEOs in older age brackets show a positive abnormal return on firm value

Yet, although CEO age and executive-employee pay gap (EEPG) are readily observable, there is surprisingly little evidence on how a CEO's age affects the decision of EEPG in the CEO's corporate. EEPG is a critical organizational policy, which would determine the behavior choices of the top executives, the employees and thus firm performance to a large degree. CEOs with different ages would naturally have the willingness to manipulate EEPG according their own favorites in order to accomplish their own objectives, which may not be the same the organizational objectives. The paper tries to investigate the relationship between CEO age and EEPG by taking the Chinese listed manufacturing companies over 2010-2014 as the sample.

The new finding of the study is that CEO age has positive effect on EEPG in Chinese listed manufacturing companies, which means older CEOs have stronger intention to enlarge EEPG out of their risk aversion, while younger 
CEOs have an intention to control the unlimited growth of EEPG out of their firm-served motivations and career concerns.

The next parts of this paper are arranged as follows: section II provides the literature and hypothesis, section III describes the research method and research sample, section IV provides the empirical results and discussion, and the final section is the conclusions.

\section{Literature and hypothesis}

Incentives compensation, as a frequently used incentives in business practice, has always been a hot topic in theorists, especially its antecedents and real effect on firm performance. EEPG, as one of such main incentives pay methods, is one of the critical issues of corporate governance in Chinese listed companies, and its wild growth is receiving more and more attention from researchers all across the world. Based on the extant literature, beyond all question, EEPG is a true sense of double-edged sword which can potentially and essentially improve or harm firm performance. It means that the function mechanisms of EEPG's effect on firm performance are complicated and it is rather difficult to understand accurately.

EEPG may have both positive effects proposed by the scholars holding tournament theory and negative effects proposed by the scholars holding behavioral theory on firm performance at the same time. However, each effect has its preconditions for getting a dominant position compared with another effect. In other words, different contextual factors will adjust the relative strength of the two EEPG's opposite effects on firm performance. On one side, when EEPG is not too large and the cooperation among employees and top manages is of high performance consequences, the positive effect derived from interpersonal competition and financial incentives due to higher EEPG will beat the negative effects; On the other side, under some other conditions, for example, the relationship among top manages and front-line employees is poor and EEPG is already too large, the negative effects derived from the counterproductive behavior and bad emotions due to higher EEPG will beat the positive effects. Consequently, for scholars, it is critical to find out such contextual antecedents and further investigate its effect on EEPG.

CEOs are responsible for maximizing their companies' value. Though such core function applies to all employees in a firm, the CEO ultimately is responsible for this central task of business, and reports directly to the board of the directors of [11]. Because CEOs bear this ultimate accountability, they are commonly given rather broad authority within their companies and are charged with the overarching leadership, strategy, and direction of their firm running. Therefore, CEOs would certainly be also charged with the setting of EEPG. Different characteristics of CEOs would have essential effect on their choices on different level of EEPG.

Age has been demonstrated to affect personal risk taking in general and more specifically corporate risk taking. For one thing, many studies investigate the role of investors' age on portfolio choices. For example, Ackert et al. (2002) find investors age is closely related to a lower percentage of their risky assets in equities [12], as compared to bonds, consistent with increasing risk aversion with age. Similarly, Bodie and Crane (1997) indicate investors age is significantly and negatively related to percentage of risky assets held in equity [13], while Samanez-Larkin et al. (2010) find unique effects of investors age on risk taking in financial decision making [14]. For another thing, some other studies study risk taking by managers in a corporate setting. For example, Vroom and Pahl (1971) find older managers are more risk averse by adopting a questionnaire administered to managers [15]. Wiersema and Bantel (1992) argue that the firms most likely to undergo changes in strategy generally have top management teams with lower average age[16]. Therefore, we hold the view that older CEOs have higher risk preferences. From the perspective of risk-aversion, CEO age has significant association to the setting of EEPG.

First, older CEOs intend to empower employees with relatively more limited discretion in order to control the possible risks for unexpected consequences potentially derived from the discretionary behavior of the widely distributed employees both regionally and emotionally. Employee discretion would not only enlarge employees' bargaining power with the executives on compensation issues, but enhance employees' potential capability in determining firm performance. In this way, higher employee discretion would necessarily be correlated to higher employees' wage. Since older CEOs want to limit employee discretion, then employee compensation would be limited to a lower degree. Here, given the level of executive compensation, lower employee pay would lead to larger EEPG.

Second, older CEOs intend to delegate executives with relatively higher discretion in order to minimize the possible operation risks due to CEOs' limited energy, knowledge and expertise when they run the firms completely depending on themselves. Executives with higher discretion would be motivated to work hard toward improving firm performance, and the success possibility of firm running would be improved to a better degree than that under the condition of lower executive discretion. Obviously, higher executive discretion needs the match of higher executive compensation. Simultaneously, in order to minimize the possible uncontrollable risk due to higher executive discretion, a relatively higher pay than the theoretically reasonable pay would be a good choice, which can not only motivate executives work harder, but can improve the default cost of executives when they misuse their discretion. Of course, older CEOs have better experience and capability in monitoring and evaluating their executives. In this case, under the condition of older CEOs, executive pay would be set at higher level out of the reason of risk aversion. Here, given the level of employees' compensation, higher executive pay would lead to larger EEPG.

According the discussion above, the paper proposes the following hypothesis. 
H1: CEO age has positive effect on EEPG.

\section{Method}

\subsection{Measures}

CEO age (CAGE). CAGE is measured by the number of the years from CEO's birth year to the sample year. We do decimals to round up and round down numbers.

EEPG is measured by logarithm of difference between the average of executive compensation and the average of employees' compensation [17].

Control variables. Following the popular literature in investigating the antecedents of EEPG, Seven control variables are chosen. (1) EAST is coded as 1, when the sample firm is located in the eastern China; otherwise, EAST is coded as 0. (2) LNTA is the logarithm of total assets of the sample firm. (3) ROA is the return on assets which measures firm performance. (4) RID represents the ratio of the number of independent directors to board size. (5)CSH is coded as 1 when CEO holds certain share of the listed company; otherwise, CSH is coded as o. (6)CDUA is coded as 1 when CEO also takes the position of the Chairman of the board ; otherwise, CDUA is 0; (7) TMTN represents the logarithm of the size of the top management teams.

\subsection{Sample and data}

Taking all the listed manufacturing companies which exist during 2010-2014 in Shanghai and Shenzhen stock exchange as the sample framework, the paper selects the final research sample according to the following requirements: (1) The firms should go public before 2009; (2) The firms should not be ever punished publicly by the government authorities for any reasons; (3) The firms should not be marked with ST, PT, SST, or *ST, etc.; (4) The firms should disclose all the data that the paper needs according to our measure design; (5) The firms should run relatively normally and smoothly, i.e., EEPG should be negative. According to such rules, 709 firms are chosen, and a panel sample consisting of 3495 firm-years are designed. The descriptive statistics analysis and correlation analysis results are shown in Table.1.

Table1. Descriptive statistics and correlation coefficients

\begin{tabular}{|l|c|c|c|c|c|c|c|c|c|c|c|}
\hline & Mean & $\begin{array}{c}\text { Standard } \\
\text { Deviation }\end{array}$ & 1 & 2 & 3 & 4 & 5 & 6 & 7 & 8 & 9 \\
\hline $\begin{array}{l}\text { EEPG } \\
\text { 2. }\end{array}$ & 11.990 & .962 & 1 & & & & & & & \\
\hline $\begin{array}{l}\text { CAGE } \\
\text { EAST }\end{array}$ & 52.510 & 6.929 & $.162^{* *}$ & 1 & & & & & & \\
\hline $\begin{array}{l}4 . \\
\text { LNTA }\end{array}$ & 9.570 & .514 & $.348^{* *}$ & $.110^{* *}$ & -.030 & 1 & & & & & \\
\hline $\begin{array}{l}5 . \\
\text { ROA }\end{array}$ & .600 & 2.934 & $.184^{* *}$ & $.079 * *$ & $.045^{* *}$ & $.099^{* *}$ & 1 & & & \\
\hline $\begin{array}{l}6 . \\
\text { RID }\end{array}$ & .370 & .056 & $.066^{* *}$ & -.012 & $-.042 *$ & -.004 & -.027 & 1 & & \\
\hline $\begin{array}{l}7 . \\
\text { CSH }\end{array}$ & .350 & .478 & $.242^{* *}$ & $.131^{* *}$ & $.128^{* *}$ & $.082^{* *}$ & $.071^{* *}$ & .009 & 1 & \\
\hline $\begin{array}{l}8 . \\
\text { CDUA }\end{array}$ & .210 & .405 & $.064 * *$ & $-.046^{* *}$ & .022 & $-.079 * *$ & .024 & .015 & $.170^{* *}$ & 1 & \\
\hline $\begin{array}{l}9 . \\
\text { TMTN }\end{array}$ & 17.520 & 3.915 & $.070^{* *}$ & $.037 *$ & $-.102^{* *}$ & $.425^{* *}$ & -.007 & $-.089 * *$ & -.030 & $-.160^{* *}$ & 1 \\
\hline
\end{tabular}

$\mathrm{N}=3495$

** represents significance level of 0.05

$* * *$ represents significance level of 0.01

\section{Empirical test}

\subsection{Main results}

In order to test H1, we design Model 1 based on OLS which takes EEPG as the dependent variable, CAGE as the predictor, and EAST, LNTA, ROA, RID, CSH, CDUA and TMTN as the control variables. 


$$
\begin{aligned}
E E P G_{i t} & =\alpha+\beta_{0} C A G E_{i t}+\beta_{1} E A S T_{i t}+\beta_{2} L N T A_{i t}+\beta_{3} R O A_{i t}+\beta_{4} R I D_{i t}+\beta_{5} C S H_{i t} \\
& +\beta_{6} C_{i t} D A_{i t}+\beta_{7} T M T N_{i t}+\varepsilon_{i t}
\end{aligned}
$$

The paper executes the regression analysis on Mode1 1 by adopting the panel data with 3495 firm-years. Results are shown in Table 2.

According to Table 2, the standardized regression coefficient of CAGE is $0.087(\mathrm{~T}=5.754, \mathrm{P}<0.0001)$. That means $\mathrm{H} 1$ is confirmed. Our data supports that CEO age has positive effect on EEPG. Specifically speaking, one unit change of CAGE would lead to 0.087 unit of change of EEPG toward the same direction.

With regard to the control variables, it is worthy of pointing out that: (1) Compared with the firms in western China, the firms in eastern China would generally have higher EEPG; (2) Compared the smaller firms, larger firms would favor much higher EEPG; (3) The more higher firm performance is, the higher EEPG; (4) The ratio of independent directors favor higher EEPG, instead of constraining the enlargement of EEPG, which is not confirming to our normal expectation; (5) When CEOs hold the share, EEPG would get larger, which may rely on the higher power of CEOs in determining EEPG at their own interests; (6) When CEO duality is true, EEPG is higher; (7) There is a negative relationship between the size of top management teams and EEPG.

Basically, the conclusions on the control variables are rather in agreement with the extant literature, except for the results of the ratio of independent directors. There is a good need to investigate the relationship between the ratio of independent directors and EEPG in the future study. Besides, the fact that most of the variables show similar effects with those in the other literature show that the validity of the data and methods in this study. From this perspective, the main research finding of this paper, i.e. the positive relationship between CEO age and EEPG, which is found for the first time as far as we know, can be regarded as believable.

\subsection{Robustness test}

In order to test the robustness of the empirical results, the paper uses REEP as the alternative measure of EEPG, which is calculated by the logarithm of the ratio of the average of executive compensation to the average of employees' compensation, and adopts LNCAGE as the alternative measure of CEO age, which is calculated by the logarithm of AGE. Then Model 2 is given.

$$
\begin{aligned}
R E E P_{i t} & =\alpha+\beta_{0} L_{N C A G E_{i t}}+\beta_{1} E A S T_{i t}+\beta_{2} L N T A_{i t}+\beta_{3} R O A_{i t}+\beta_{4} R I D_{i t}+\beta_{5} C S H_{i t} \\
& +\beta_{6} C D U A_{i t}+\beta_{7} T M T N_{i t}+\varepsilon_{i t}
\end{aligned}
$$

Considering the potential time lag effect of CEO age and other control variables on EEPG, the paper chooses EEPG

\begin{tabular}{|c|c|c|c|c|c|c|}
\hline \multirow{2}{*}{\multicolumn{2}{|c|}{ Model }} & \multicolumn{2}{|c|}{ Unstandardized Coefficient } & \multirow{2}{*}{$\begin{array}{c}\text { Standardized } \\
\text { Coefficient } \\
\beta\end{array}$} & \multirow[t]{2}{*}{$\mathrm{T}$} & \multirow[t]{2}{*}{ Sig. } \\
\hline & & $\mathrm{B}$ & Standardized Error & & & \\
\hline \multirow{8}{*}{ Model 1} & Constant & 4.669 & .303 & & 15.412 & .000 \\
\hline & EAST & .293 & .029 & .151 & 9.964 & .000 \\
\hline & LNTA & .635 & .031 & .339 & 20.292 & .000 \\
\hline & ROA & .041 & .005 & .126 & 8.336 & .000 \\
\hline & RID & 1.244 & .257 & .072 & 4.834 & .000 \\
\hline & $\mathrm{CSH}$ & .329 & .031 & .164 & 10.581 & .000 \\
\hline & CDUA & .127 & .036 & .054 & 3.493 & .000 \\
\hline & TMTN & -.010 & .004 & -.042 & -2.487 & .013 \\
\hline & $C A G E$ & .012 & .002 & .087 & 5.754 & .000 \\
\hline & $\mathrm{R}$ & .476 & R2 & .227 & Adjusted R2 & .225 \\
\hline
\end{tabular}
in the year of " $\mathrm{t}+1$ " as the dependent variable, while chooses the data of CEO age and all the other control variables in the year of " $t$ " as the independent variables $(t=2010,2011,2012,2013)$. Then Model 3 can be built.

Table 2. Regression results of Model 1 


\begin{tabular}{|l|c|c|c|c|c|c|}
\hline & F & 127.758 & Model Sig. & .000 & N & 3495 \\
\hline
\end{tabular}

Note: Dependent variable is EEPG.

Regression results of Model 2 with the data of the whole sample are shown in Table 3, while the regression results of Model 3 are not provided in detail due to the limitation of paper length. Both results show that H1 still holds. That is to say, CEO age is still positively related with EEPG. The result does not change with the change of variable measures, and it still does not change when we consider the time lag effect.

Table 3. Regression results of Model 2

\begin{tabular}{|c|c|c|c|c|c|c|}
\hline \multirow{2}{*}{\multicolumn{2}{|c|}{$\begin{array}{c}\text { Table } 3 \text {. Regression results of } \\
\text { Model } 2 \text { Model }\end{array}$}} & \multicolumn{2}{|c|}{ Unstandardized Coefficient } & \multirow{3}{*}{$\begin{array}{c}\begin{array}{c}\text { Standardized } \\
\text { Coefficient }\end{array} \\
\beta\end{array}$} & \multirow{3}{*}{$\begin{array}{c}\mathrm{T} \\
-9.491\end{array}$} & \multirow{3}{*}{$\begin{array}{l}\text { Sig. } \\
.000\end{array}$} \\
\hline & & \multirow{2}{*}{$\begin{array}{c}\text { B } \\
-3.377\end{array}$} & \multirow{2}{*}{$\begin{array}{c}\text { Standardized Error } \\
.356\end{array}$} & & & \\
\hline \multirow{8}{*}{ Model 2} & Constant & & & & & \\
\hline & EAST & .119 & .021 & .091 & 5.701 & .000 \\
\hline & LNTA & .329 & .022 & .260 & 14.764 & .000 \\
\hline & ROA & .014 & .004 & .065 & 4.092 & .000 \\
\hline & RID & .610 & .183 & .053 & 3.330 & .001 \\
\hline & $\mathrm{CSH}$ & .241 & .022 & .178 & 10.914 & .000 \\
\hline & CDUA & .087 & .026 & .054 & 3.364 & .001 \\
\hline & TMTN & -.014 & .003 & -.085 & -4.779 & .000 \\
\hline & $C A G E$ & .354 & .078 & .073 & 4.538 & .000 \\
\hline & $\mathrm{R}$ & .375 & $\mathrm{R} 2$ & .141 & Adjusted $\mathrm{R}^{2}$ & .139 \\
\hline & $\mathrm{F}$ & 71.478 & Model Sig. & .000 & $\mathrm{~N}$ & 3495 \\
\hline
\end{tabular}

Note: Dependent variable is REEP.

\subsection{Discussion}

Our theoretical analysis and empirical data show that CEO age is positively related to EEPG in Chinese listed manufacturing companies. The fact indicates that older CEOs favor higher EEPG. Though the main reasons of such a result have been explained to good degree from the risk aversion perspective in section 2, there still are some other alternative perspectives.

For example, a possible perspective may rely on the CEO's affiliation needs to his or her closest workmates, i.e., the top executives. Older CEOs would favor interpersonal relationship of better quality than younger CEOs would, and especially it is true in China. The fulfillment of CEO's affiliation needs mainly comes from the good relationship between CEOs and their executives, because they work together with the highest frequency and the longest time. In this case, older CEOs intend to provide their executives with higher compensation than the reasonable level it should be. Here, EEPG gets larger and larger with the implementation of meeting CEO's affiliation needs.

Another possible perspective may rely on the various degrees of familiarity of older CEOs with their top executives and the employees. Besides the possible differences in personal feelings, older CEOs would have much higher recognition on top executives' capability and they would think the top executives make higher contributions to firm performance than the front-line employees do. Even being out of firm-served motivations, older CEOs would enlarge EEPG since they know the capability and performance of top executives much better than they know those of the employees.

\section{Conclusions}

This paper investigates the role of CEO age in determining EEPG from the perspective of CEO's risk aversion, which has not been explored till today by the scholars. Data from the Chinese listed manufacturing companies over 2010-2014 
prove that CEO age can improve the enlargement of EEPG out of the purpose of lowering the operation risks. It is a new finding of great significance since it does break the traditional view on the differences between older CEOs and younger CEOs in China, which thinks the former would favor more equal distribution than the later do. The fact is that older CEOs would enlarge EEPG at their own discretion. When facing the situation of letting older CEOs set their firm's EEPG, the board and the shareholders should pay more attention to the possible unreasonable enlargement of EEPG, since the older CEOs are more self-served and risk-averse; while when the newer CEOs are setting the EEPG, higher discretion should endowed to them since they are more firm-served with great passion.

In the future, more empirical studies should be done in the following aspects: (1) Samples should go beyond the limitation of manufacturing companies; (2) Methods should adopt more strict empirical models which consider the possible endogenous problems; (3) The measure of EEPG should be refined to a better degree according to the newest accounting practices.

\section{Acknowledgements}

This research was supported by Projects of the National Social Science Foundation of China under the Grant "15BGL109".

\section{References}

1. Carpenter, Mason A.,. The Handbook of Research on Top Management Teams (Edward Elgar Publishing, Inc., Northampton, MA). (2011)

2. Musteena, Martina, Vincent L. Barker IIIa and Virginia L. Baeten, CEO attributes associated with attitude toward change: The direct and moderating effects of CEO tenure, Journal of Business Research 59, 604-612. (2006)

3. Malmendier, U., \& Tate, G. Who makes acquisitions? CEO overconfidence and the market's reaction. Journal of Financial Economics, 89, 20-43 (2008)

4. Elsaid, Eahab and Ursel, Nancy D. Age, CEO succession, and risk taking. Accounting and FinanceResearch,1(2).76-86. http://scholar.uwindsor.ca/odettepub/13 (2012)

5. Matthew A. Serfling. CEO age and the riskiness of corporate policies. Journal of Corporate Finance, Volume 25, Pages 251-273 (April 2014)

6. Chevalier, J., Ellison, G.. Career concerns of mutual fund managers. Quarterly Journal of Economics 114, 389-432 (1999)

7. Bertrand, Marianne, and Antoinette Schoar, Managing with style: The effect of managers on firm policies, Quarterly Journal of Economics 118, 1169-1208 (2003)

8. Wallace N. DavidsonIII, Biao Xie, Weihong Xu, Yixi Ning. The influence of executive age, career horizon and incentives on pre-turnover earnings management, Journal of Management \& Governance. Volume 11, Issue 1, pp 45-60 (March 2007)

9. Nulla, Yusuf Mohammed, The Effect of CEO Age on CEO Compensation Using Accounting Performance as a Benchmark: An Empirical Study on NYSE Index Companies. Journal of Management Policies and Practices, March 2014, Vol. 2, No. 1, pp. 119-133 (June 8, 2014)

10. D'Ewart, Brandon H., "The Effect of CEO Gender, Age, and Salary On Firm Value". CMC Senior Theses. Paper1059.http://scholarship.claremont.edu/cmc_theses/1059 (2015)

11. Lin, Tom CW. "CEOs and Presidents." UC Davis Law Review 47: 1351. Web. 9 (Nov.2014)

12. Ackert, L., Church, B., \& Englis, B. The asset allocation decision and investor heterogeneity: A puzzle? Journal of Economic Behavior and Organization, 47 (4), 423-433 (2002)

13. Bodie, Z., \& Crane, D. Personal investing advice, theory, and evidence. Financial Analysts Journal, 53 (6),13-23 (1997)

14. Samanez-Larkin, G., Kuhnen, C., Yoo, D., \& Knutson, B. Variability in nucleus accumbents activity mediates agerelated sub-optimal financial risk taking. Journal of Neuroscience, 30, 1426-1434 . (2010)

15. Vroom, V., \& Pahl, B. Relationship between age and risk taking among managers. Journal of Applied Psychology, 55 (5), 399-405 (1971)

16. Wiersema, M., \& Bantel, K. Top management team demography and corporate strategic change. Academy of Management Journal, 35 (1), 91-121. http://dx.doi.org/10.2307/256474 (1992)

17. Taekjin Shin. Explaining Pay Disparities between Top Executives and Non-executive Employees: A Relative Bargaining Power Approach, Social Forces Volume 92, Number 4, pp. 1339-1372 (June 2014) 